\title{
La Elegy Written in a Country Churchyard de Thomas Gray: traducción castellana
}

M. A. García Peinado y M. Vella Ramírez

Universidad de Córdoba (España)

Ningún problema tan consustancial con las letras y con su modesto misterio como el que propone una traducción.

Jorge Luis Borges, Las versiones homéricas

\section{Introducción}

La tarea de traducir, actualmente tan en boga, se revela enormemente difícil para cualquiera que lo intente; el traductor sabe por propia experiencia que aunque como técnico de la traducción debe tener un conocimiento exacto de todas las equivalencias "corrientes" o "normales", ello no le será suficiente para pasar adecuadamente un texto de una lengua a otra. $\mathrm{Y}$ es que, como ya afirmaba nuestro buen amigo el lingüista Eugenio Coseriu:

El error básico radica en el hecho de situar la operación traductora en el plano de las lenguas y considerar que traducir no es sino transponer las significaciones de una lengua en significaciones de otra lengua. Porque, en realidad, las lenguas no se traducen: no son el objeto, sino que, con su estructura material y semántica, son el instrumento o medio de la traducción. El verdadero objeto de la traducción son los "discursos" o "textos". Se traduce, por cierto, por medio de las lenguas, pero se traducen siempre discursos (o textos); y lo que se traslada son los "contenidos textuales", no los "contenidos de lengua".

Desde hace ya bastante tiempo, la traducción parece destinada a ilustrar la discusión estética; no obstante, pensamos que hay que llegar a la teoría desde la práctica y, a ese respecto, el modo más fácil para aprender a traducir bien es "dejarse guiar por buenos maestros". ${ }^{2}$ Trabajo difícil sin embargo de llevar a la práctica y más aún en el caso de la traducción poética, que se convierte con frecuencia en un delicado y largo proceso que obliga a estudiar durante un tiempo (que en ocasiones se convierte en estático al estancarse el traductor en un poema o un verso difícil de resolver) significados dudosos, oscuridades, juegos verbales, diferencias de estilo, contrastes, etc.; pero, ¡qué goce mental tan intenso produce el resolver un enigma, encontrar el término exacto, dar con la palabra buscada! o cuando el traductor cree haber encontrado el "equivalente emocional del pensamiento" del que habla Eliot y que lleva a que una buena traducción posibilite el que un poema no pierda sus valores poéticos al ser traducido a otra lengua, a pesar de que se pierdan los valores propios de la lengua original. Como alguna vez ha afirmado un excelente crítico y traductor de poesía: 
Re/producir significa en concreto lo que etimológicamente señala el término: producir de nuevo. Si escribir es producir un espacio (simbólico) a través del discurso, traducir consiste en una tarea similar: re/construir, en su sentido más amplio, un objeto poético desde su propia e inherente individualidad en un sistema diferente. Uno de los componentes de esta individualidad, pero no el único, es el uso de una lengua distinta de aquélla a la cual el texto está siendo traducido. Por ello, traducir exige mucho más que verter mecánicamente de un recipiente en otro: implica reescribir el objeto, que es sólo uno de los elementos del universo de sentido que le da consistencia, para contextualizarlo en un espacio cultural distinto. Traducir no produce un espacio similar sino un nuevo espacio discursivo y textual, cuyas relaciones con lo que definimos como original, por mucho que lo acerquen, no llegan a confundirlo con él. Un texto es una totalidad dialógica que excede los límites estrictamente lingüísticos e impone al traductor la necesidad de traducirlo como tal totalidad. Por eso, la lectura de un texto traducido no debería ser entendida como una ilustración o una explicación, sino como la realización de las posibilidades significativas del texto original. Es un nuevo punto de partida, no de llegada. ${ }^{3}$

Nada que objetar a esta acertada disección del proceso de traducción, sí acaso añadir que una buena traducción castellana debe "sonar" en castellano como poema intentando, al tiempo, ser fiel al original; digamos, para terminar esta breve introducción al proceso traductorio de un modo poético, que no se traduce el sonido de las sílabas, sino que se traduce su vibración en el alma que es lo que importa. Lo demás, fácilmente lo adivinará quienquiera que tenga sentido poético.

\section{Thomas Gray (1716-1771)}

El autor de la Elegy Written in a Country Churchyard, publicada en 1751, ha venido siendo inscrito en dos corrientes o estéticas literarias, consecuencia una de la otra; nos referimos en primer lugar a la denominada "Poetry of Sensibility" por los estudiosos de ese período de la literatura inglesa, y que en realidad no es más que una ruptura con la etapa neoclásica precedente tendente a la disciplina y la norma, en la cual el poeta está llamado a ser un artesano que debe construir bellas composiciones estéticas, inspiradas generalmente en los clásicos. Se puede afirmar que junto a William Collins (1721-1759), Gray representa la transición entre el mundo neoclásico citado y la posterior etapa romántica; nuestro poeta combina en sus obras la perfección formal y temática de la etapa anterior con la inspiración y temperamento románticos. Preciso es decir, aunque no es nada novedoso, que repetidamente se ha hablado de que existía ya un "romanticismo" en el siglo XVIII; lo podemos hallar en Inglaterra en las poesías del falso Ossián y en el retorno a la Edad Media, en Francia, en la prosa de Jean-Jacques Rosseau (La Nouvelle Hélö̈se), en la búsqueda de felicidad imposible del "abbé" Prévost, en el género "troubadour” otra vez de moda y en la búsqueda del Edén inaccesible de Bernardin de Saint-Pierre. Algunos poetas ingleses basán- 
dose en todas estas características ponen de moda una poesía atribulada, como reacción posiblemente a la vacuidad de la poesía de su época. Este sentimiento "melancólico" aparece fundamentalmente en la elegía, apta para expresar todas las tonalidades de la melancolía naciente, que por su matiz de desencanto, a menudo lúgubre, reúne todos los ingredientes para alejar al lector de la normativa clásica y proporcionarle la idea de un nuevo sentimiento.

El representante más cualificado de esta "Poetry of Sensibility" es, sin ningún género de dudas, Thomas Gray que participa también de la estética denominada "Graveyard School" que incluye asimismo, con trabajos publicados anteriormente a su Elegy, a Edward Young y sus Night Thoughts (1741), Robert Blair y The Grave (1743), y James Hervey y su obra en prosa poética Meditations Among the Tombs (1748). La "Graveyard School" expandió su influencia prácticamente a toda Europa ${ }^{4}$ recibiendo nombres muy similares: "poesía de las tumbas", "poseía de los cementerios", "poesía sepulcral", gozando de un gran éxito como demuestran Gräbertrachtungen (1763) del alemán Nürnberger, las Noches lúgubres (1792) del español Cadalso, Tombeaux (1794) del francés Augustin-François Creuzé de Lesser, Dei Sepolcri (1807) del italiano Foscolo y Sepultures (1813) del primer gran poeta romántico francés Lamartine.

La Elegy Written in a Country-Churchyard (1751) de Thomas Gray es a la vez una fresca evocación de la vida de un pueblecito ${ }^{5}$ y una meditación profunda sobre la fragilidad de la vida; por influencia de este pequeño poema de 128 versos el encanto directo de la vida campesina va a infiltrarse en la literatura. Podemos afirmar que setenta años antes de las Méditations (1820) de Lamartine, obra que tradicionalmente se ha considerado como el inicio del Romanticismo en Francia, la Elegy de Gray en una obra ya muy lamartiniana.

\section{Traducciones de la obra}

La brevedad del poema (128 versos) ha animado a los traductores a reproducirlo en distintas lenguas; antes de $1830 \mathrm{el}$ poema había sido traducido ya en noventa y dos ocasiones. Destacables son entre las primeras, la traducción al alemán de Gotter en 1771 y, por su rareza, la realizada en París a principios del siglo XIX (1802), que incluía el texto de Gray con traducciones interlineales al francés, al alemán, al sueco, al danés, al portugués y al hebreo.

Por lo que respecta a las traducciones al castellano, citemos la del poeta argentino José Antonio Miralla (1789-1825), llevada a cabo en endecasílabos rimados y que lleva por título Elegía en el cementerio de una aldea; de 1860 es la versión de H. L. de Vedia, Elegía escrita en un cementerio campestre, realizada en verso y publicada en Liverpool (Imprenta de Rockliff hermanos); mucho más conocida es la traducción de don Miguel de Unamuno, que también la contrastó en su Elegía en un cementerio castellano, poema de sesenta versos escrito en 1913; por último, entre las más recientes, ha sido muy difundida la versión de Angel Rupérez. ${ }^{6}$ 


\section{Elegy written in a country churchyard: versión al castellano}

\section{Elegy written in a country churchyard}

1 The curfew tolls the knell of parting day, 2 The lowing herd wind slowly o'er the lea, 3 The plowman homeward plods his weary way, 4 And leaves the world to darkness and to me.

5 Now fades the glimm'ring landscape on the sight, 6 And all the air a solemn stillness holds,

7 Save where the beetle wheels his droning flight,

8 And drowsy tinklings lull the distant folds;

9 Save that from yonder ivy-mantled tow' $r$

10 The moping owl does to the moon complain 11 Of such, as wand'ring near her secret bow'r, 12 Molest her ancient solitary reign.

13 Beneath those rugged elms, that yew-tree's shade, 14 Where heaves the turf in many a mould'ring heap, 15 Each in his narrow cell forever laid,

16 The rude forefathers of the hamlet sleep.

17 The breezy call of incense-breathing Morn, 18 The swallow twitt' ring from the straw-built shed, 19 The cock's shrill clarion, or the echoing horn, 20 No more shall rouse them from their lowly bed.

21 For them no more the blazing hearth shall burn,

22 Or busy housewife ply her evening care:

23 No children run to lisp their sire's return,

24 Or climb his knees the envied kiss to share.

25 Oft did the harvest to their sickle yield,

26 Their furrow oft the stubborn glebe has broke;

27 How jocund did they drive their team afield!

28 How bow'd the woods beneath their sturdy stroke!

29 Let not Ambition mock their useful toil, 30 Their homely joys, and destiny obscure; 31 Nor Grandeur hear with a disdainful smile 32 The short and simple annals of the poor.

33 The boast of heraldry, the pomp of pow'r, 34 And all that beauty, all that wealth e'er gave, 35 Awaits alike th' inevitable hour.

36 The paths of glory lead but to the grave.

\section{Elegía escrita en un cementerio de aldea}

El toque de campana dobla al caer la tarde, y el balar del rebaño cruza tranquilo el prado; vuelve a casa el labriego con su paso cansado, dejándonos el mundo a la noche y a mí.

el desvaído paisaje va perdiendo colores y en todo el aire flota una solemne calma, que sólo rompe el ruido del moscardón volando y el cencerreo monótono de lejanos rebaños;

de la torre a lo lejos recubierta de hiedra la afligida lechuza a la luna se queja de los que merodean por sus íntimas ramas, perturbando su antiguo y desierto dominio.

Bajo estos toscos olmos, a la sombra del tejo, donde la hierba crece en sinuosos montones, yaciendo para siempre, en sus angostas celdas, los sencillos ancestros de la aldea reposan.

Ni el alegre reclamo del alba perfumada, el vencejo gorjeando sobre los cobertizos, el gallo cantarín o el eco de las cuernas podrán ya levantarlos de sus humildes lechos.

Para ellos nunca más calentará ya el fuego, ni la ajetreada esposa le ofrecerá sus mimos: no habrá niños que corran gangueando a su regreso trepando a sus rodillas para el deseado beso.

Con frecuencia a su hoz se rendían las cosechas y su surco ya ha roto la endurecida tierra. ¡Cuán felices guiaban sus yuntas por el campo! ¡Cómo ante su firme hacha se rendían los bosques!

Que la Ambición respete su provechoso esfuerzo, sus gozos hogareños y su destino oscuro; que la Grandeza escuche sin risa desdeñosa las sencillas y simples historias de los pobres.

La gloria de la heráldica, la pompa del poder, y todo lo que aportan la riqueza y belleza aguardan por igual la inevitable hora: los senderos de gloria conducen a la tumba.

37 Nor you, ye proud, impute to these the fault, Y vosotros, altivos, no los culpéis del hecho 
38 If Mem'ry o'er their tomb no trophies raise, 39 Where thro' the long-drawn aisle and fretted vault 40 The pealing anthem swells the note of praise.

41 Can storied urn or animated bust

42 Back to its mansion call the fleeting breath?

43 Can Honour's voice provoke the silent dust,

44 Or Flatt'ry soothe the dull cold ear of Death?

45 Perhaps in this neglected spot is laid

46 Some heart once pregnant with celestial fire;

$47 \mathrm{Hands}$, that the rod of empire might have sway'd,

48 Or wak'd to ecstasy the living lyre.

49 But Knowledge to their eyes her ample page

50 Rich with the spoils of time did ne'er unroll;

51 Chill Penury repress'd their noble rage,

52 And froze the genial current of the soul.

53 Full many a gem of purest ray serene,

54 The dark unfathom'd caves of ocean bear:

55 Full many a flow'r is born to blush unseen,

56 And waste its sweetness on the desert air.

57 Some village-Hampden, that with dauntless breast 58 The little tyrant of his fields withstood;

59 Some mute inglorious Milton here may rest,

60 Some Cromwell guiltless of his country's blood.

61 Th' applause of list'ning senates to command,

62 The threats of pain and ruin to despise,

63 To scatter plenty o'er a smiling land,

64 And read their hist'ry in a nations eye's,

65 Their lot forbade: nor circumscrib'd alone

66 Their growing virtues, but their crimes confin'd;

67 Forbade to wade through slaughter to a throne,

68 And shut the gates of mercy on mankind,

69 The struggling pangs of conscious truth to hide, 70 To quench the blushes of ingenious shame,

71 Or heap the shrine of luxury and Pride

72 With incense kindled at the Muse's flame.

73 Far from the madding crowd's ignoble strife, 74 Their sober wishes never learn'd to stray; 75 Along the cool sequester'd vale of life 76 They kept the noiseless tenor of their way.

77 Yet ev'n these bones from insult to protect, 78 Some frail memorial still erected nigh, de que en sus tumbas no haya trofeos a la Memoria ${ }^{7}$, mientras que en los pasillos largos, de rancias criptas, el sonoro motete aumenta la alabanza.

¿Pueden urnas grabadas o bustos animados hacer volver a casa el efímero hálito? ¿Puede la voz altruista retar al mudo polvo o ablandar los halagos a la fría y sorda muerte?

En este sitio ausente, quizá puede que duerma algún alma insuflada de fuego celestial o unas manos que asieran el cetro del imperio, o que a la eterna lira al éxtasis llamaran.

Pero el Conocimiento a sus ojos jamás desplegó su amplia página con el saber del tiempo; la gélida Penuria reprimió su noble ira, helando en esas almas su torrente genial.

Muchas piedras preciosas del más puro color soportan sombrías cuevas del insondable océano: muchas flores se abren sin que nadie las vea y malgastan su aroma en el aire desierto.

Algún Hampden ${ }^{8}$ aldeano, que con corazón bravo soportó al tiranuelo que mandaba en sus campos; algún callado Milton o algún Cromwell sin culpa de la sangre en su tierra, puede que aquí descansen.

Ordenar el aplauso del paciente senado, despreciar la miseria y el reto del dolor, distribuir la abundancia sobre risueñas tierras y contar sus historias a ojos de la nación

prohibióselo la suerte: no sólo limitando sus crecientes virtudes sino también sus crímenes; prohibióles alcanzar con masacres el trono y cerrarles las puertas de la piedad a los hombres,

ocultar las punzadas de la verdad consciente, sofocar los rubores de la ingenua vergüenza o colmar los altares del Orgullo y Lujuria con incienso prendido en llamas de la Musa.

Lejos de las refriegas de las turbas febriles sus sensatos deseos nunca fueron erróneos; junto al frío y recluido páramo de la vida transcurrió silencioso el curso de su viaje.

Y así, por proteger estos huesos de ultrajes muy cerca se erigieron frágiles monumentos 
79 With uncouth rhymes and shapeless sculpture deck'd,

80 Implores the passing tribute of a sigh.

81 Their name, their years, spelt by th' unletter'd muse,

82 The place of fame and elegy supply:

83 And many a holy text around she strews,

84 That teach the rustic moralist to die.

85 For who to dumb Forgetfulness a prey, 86 This pleasing anxious being e'er resign'd,

87 Left the warm precincts of the cheerful day,

88 Nor cast one longing, ling'ring look behind?

89 On some fond breast the parting soul relies, 90 Some pious drops the closing eye requires; $91 \mathrm{Ev}$ 'n from the tomb the voice of Nature cries, 92 Ev'n in our ashes live their wonted fires.

93 For thee, who mindful of th' unhonour'd Dead 94 Dost in these lines their artless tale relate; 95 If chance, by lonely contemplation led,

96 Some kindred spirit shall inquire thy fate,

97 Haply some hoary-headed swain may say, 98 "Oft have we seen him at the peep of dawn 99 Brushing with hasty steps the dews away 100 Too meet the sun upon the upland lawn.

101 "There at the foot of yonder nodding beech

102 That wreathes its old fantastic roots so high,

103 His listless length at noontide would stretch, 104 And pore upon the brook that babbles by.

105 "Hard by yon wood, now smiling as in scorn, 106 Mutt'ring his wayward fancies he would rove, 107 Now drooping, woeful wan, like one forlorn, 108 Or craz'd with care, or cross'd in hopeless love.

109 "One morn I miss'd him on the custom'd hill, 110 Along the heath and near his fav'rite tree;

111 Another came; nor yet beside the rill, 112 Nor up the lawn, nor at the wood was he;

113 "The next with dirges due in sad array 114 Slow thro' the church-way path we saw him borne.

115 Approach and read (for thou canst read) the lay, 116 Grav'd on the stone beneath yon aged thorn." adornados con toscas esculturas y versos,

implorando al transeúnte la ofrenda de un suspiro.

Sus nombres y sus años la inculta musa enuncia,

la causa de su fama y la razón del poema: y siembra junto a ellos muchos textos sagrados que enseñan a morir al moralista aldeano.

¿Quién sintiéndose presa del estúpido olvido renunció a una existencia ávida y agradable dejando atrás lo cálido de los días felices, sin mirar hacia atrás con tenaz añoranza?

El alma que se marcha confía en un cuerpo amado, los ojos que se cierran requieren llanto amigo; desde la tumba incluso la Natura nos llama y hasta en nuestras cenizas sus anhelos habitan.

A ti, que te preocupas por los muertos anónimos estas líneas te narran sus sencillas historias; si alguna vez guiada por su retraída vida se acercara algún alma a conocer tu sino,

podría un zagal granado decir alegremente: "Con frecuencia lo vimos al despuntar el alba con paso presuroso evitando el rocío para el sol descubrir en los prados del valle.

Allí, al pie de aquella combada y lejana haya que ascendiendo retuerce sus míticas raíces, su longitud indolente al mediodía alargaba ${ }^{9}$ y en sonoros arroyos fijaba la mirada.

Junto a aquel bosque estaba sonriendo desdeñoso, vagaba murmurando veleidosas quimeras, cabizbajo, afligido, cual niño abandonado, de preocupación loco o por amor herido.

Un día noté su ausencia por la colina amiga, al lado de los brezos, junto a su árbol querido; y transcurrió otro día: mas ya no lo encontraron ni al lado del arroyo, en el bosque o el prado;

Al siguiente, con cánticos y vestidos de luto, lentamente a la iglesia vimos que lo llevaban.

Acércate (tú puedes) y lee esta inscripción grabada aquí en la lápida bajo el vetusto espino". 
117 Here rests his head upon the lap of Earth 118 A youth to Fortune and to Fame unknown. 119 Fair Science frown'd not on his humble birth, 120 And Melancholy mark'd him for her own.

121 Large was his bounty, and his soul sincere, 122 Heav'n did a recompense as largely send: 123 He gave to Mis'ry all he had, a tear, 124 He gain'd from Heav'n ('twas all he wish'd) a friend.

125 No farther seek his merits to disclose,

126 Or draw his frailties from their dread abode, 127 (There they alike in trembling hope repose) 128 The bosom of his Father and his God.
Aquí yacen los restos, en la tierra materna, de un joven ignorado por la Fama y Fortuna; bien aceptó la Ciencia su humilde nacimiento, Melancolía marcólo como si fuera suyo.

Tan grande fue su entrega como su alma sincera, por eso envióle el Cielo una gran recompensa: su fortuna (una lágrima) se la dio a la Miseria, un amigo (su anhelo) arrebatóle al cielo.

Para poder contarlos no examines sus méritos allí también reposan con trémula esperanza el seno de su Padre y el seno de su Dios.

${ }^{1}$ Coseriu, E. (1997): “Alcances y límites de la traducción” en Lexis, Vol. XXI, nº 2, pp. 167-168.

${ }^{2}$ Opinión sustentada constantemente por uno de los mejores traductores españoles, Valentín García Yebra, autor de los dos volúmenes de Teoría y práctica de la traducción, que fue premiado por la Real Academia Española en 1982.

${ }^{3}$ TAlens, J.: "El poeta como traductor" en $A B C$ Cultural, 1 de octubre de 1998 , p. 16.

${ }^{4}$ Todavía es ilustrativo sobre este punto concreto el trabajo de Paul Van Tieghem: "La Poésie de la Nuit et des Tombeaux en Europe au XVIIIe siècle", en Le Préromantisme, tomo II, París, 1930.

${ }^{5}$ Se piensa que Gray se inspiró en el cementerio de la iglesia de St Giles, en Stoke Poges, lugar donde se encuentra la tumba del poeta.

${ }^{6}$ Rupérez, A. (2000): Antología de la poesía inglesa, Madrid, Austral.

${ }^{7}$ En este verso hemos optado por una versión que "clarifique" el sentido y la intención del poeta: éste, quiere distinguir de un modo muy preciso la diferencia que hay entre las tumbas de los ricos y las de los pobres, y cómo estos últimos no tienen evocación alguna de un "pasado" o "recuerdo" ("Memory").

${ }^{8}$ Hampden pertenecía a una familia acomodada de Buckinghamshire con larga tradición al servicio de la Corona. Sin embargo, su tremenda oposición al gobierno arbitrario de Carlos I consiguió que el Parlamento se volviera a restablecer en 1640 , tras un período de inactividad de 11 años. Esta acción hizo que haya pasado a la historia con el sobrenombre de "El Patriota".

Digamos, asimismo, que los tres personajes mencionados en esta estrofa sustituyeron a los originarios latinos: En Stanzas wrote in a Country Churchyard, considerada la primera redacción de la Elegy, esta comparación se establece con Cato, Tulo y César; pero en la versión definitiva las 
referencias romanas fueron sustituidas por referencias inglesas (Hampden, Milton y Cromwell), seleccionando tres personajes que surgieron de pequeños pueblos y pasaron a formar parte del panorama nacional.

${ }^{9}$ La mayoría de los traductores de Gray no parecen haber interpretado correctamente este verso, pues es evidente que el autor se refiere al momento del mediodía en el cual la posición del sol vuelve más alargada la sombra del haya; digamos a este respecto que ya el propio Gray, en una carta a su amigo Walpole, que a continuación transcribimos, hizo referencia a las hayas cercanas a su casa:

"I have at the distance of half-a-mile, through a green lane, a forest (the vulgar call it a common) all my own, at least as good as so, for I spy no human thing in it but myself. It is a little chaos of mountains and precipices; mountains, it is true, that do not ascend much above the clouds, nor are the declivities quite so amazing as Dover cliff; but just such hills as people who love their necks as well as I do may venture to climb, and craggs that give the eye as much pleasure as if they were dangerous: Both vale and hill are covered with most venerable beeches, and other very reverend vegetables, that, like most other ancient people, are always dreaming out their old stories to the wind..." 